\title{
Understanding disruptive technology transitions in the global logistics industry: the role of ecosystems
}

\section{Jasmin Mikl}

Institute for Transport and Logistics Management, Vienna University of Economics and Business, Vienna, Austria

\section{David M. Herold}

Institute for Transport and Logistics Management,

Vienna University of Economics and Business, Vienna, Austria and

Business Strategy and Innovation, Griffith University, Southport/Gold Coast, Australia

Kamila Pilch and Marek Ćwiklicki

Department for Management of Public Organizations,

Cracow University of Economics, Cracow, Poland, and

\section{Sebastian Kummer}

\section{Department of Logistics, School of Management, Jilin University, Changchun, China}

Keywords Disruption, Logistics, Technology substitution, Disruptive technologies

Paper type Research paper

(C) Jasmin Mikl, David M. Herold, Kamila Pilch, Marek Ćwiklicki and Sebastian Kummer. Published by Emerald Publishing Limited. This article is published under the Creative Commons Attribution (CC BY 4.0) licence. Anyone may reproduce, distribute, translate and create derivative works of this article (for both commercial and non-commercial purposes), subject to full attribution to the original publication and authors. The full terms of this licence may be seen at http://creativecommons.org/licences/by/4.0/legalcode

\begin{abstract}
Purpose - Disruptive technologies in the global logistics industry are often regarded as a threat to the existing business models of incumbents' companies. Existing research, however, focuses mainly on whether technologies have disruptive potential, thereby neglecting when such disruptive transitions occur. To understand the timing of potential disruptive technological change, this paper aims to investigate the elements of the underlying ecosystem shaping these transitions.

Design/methodology/approach - Building on the established ecosystem framework from Adner and Kapoor (2016a), this paper constructs four categories of technology substitution to assess how quickly disruptive change may occur in the global logistics industry and defines key technology substitution determinants in logistics to emphasize the role of ecosystems for further consideration into disruptive innovation theory.

Findings - Based on the key determinants, this paper proposes first definitions of distinctive ecosystems elements linked to the three types of innovations, namely, sustaining innovations, low-end disruptions and new-market disruptions, thereby integrating ecosystems into Christensen's (1997) disruptive innovation theory.

Originality/value - By developing a framework that conceptualizes the pace of technology substitution, this paper contributes to a more nuanced understanding of how logistics managers and academics can better predict disruptive transitions and develop strategies to allocate resources.
\end{abstract}

Technology transitions

Received 10 July 2020 Revised 28 September 2020 Accepted 10 October 2020 


\section{Introduction}

Disruptive innovations within the global logistics industry are of increasing strategic importance for businesses and corporations as it impacts established paradigms, business models and industry boundaries (Barrett et al., 2015; Chapman et al., 2003; Cichosz et al., 2020; Dobrovnik et al., 2018; Goldsby and Zinn, 2016; Klötzer and Pflaum, 2017). For example, incumbent companies are challenged by disruptive technologies from logistics start-ups that offer a range of services traditionally provided by established logistics companies or providers (Bharadwaj et al., 2013; Hooper and Holtbrügge, 2020; Sandström et al., 2009; Sucky and Asdecker, 2019; Tsiulin et al., 2020).

So far, most of the disruptive technology research has emphasized a rather static view and has mostly focused on outputs, in particular on specific cases attempting to explain whether a disruptive technology substitution occurs (Cohen, 2018; Kothman and Faber, 2016), thereby neglecting the timeframes under which such transitions materialize. Research shows that technology transitions in the global logistics industry are characterized by significantly different timeframes: for example, one of the most frequent named innovations in the global logistics industry is containerization, which can be regarded as a prerequisite for today's globalization. Containerization was not only a crucial factor due to the reduction in sea freight costs but also for its dramatically saving in time in loading and unloading (Hayut, 1981; Notteboom and Rodrigue, 2009). However, the adoption of containerization in the shipping industry stretched from 1960 to 1980 , i.e. only gradual substitution can be observed, which can be attributed mainly to legacy systems and capital-intensive equipment (Rodrigue, 2016). In contrast, the adoption of and the substitution to electric conveyor belts in warehouses to distribute shipments to couriers for the last-mile delivery happened in a much shorter timeframe (Kohli, 2007; Vrgoč and Čerić, 1988). That is, among other factors, because the adoption of electronic conveyor belts is not dependent on extensive external complementary parts, thus the new technology can be implemented and integrated relatively quickly.

Drawing on both examples and their different pace of substitution, research has shown the importance of interdependence involving network externalities such as complementary products, markets and compatibility (Autry and Griffis, 2008; Bowersox and Daugherty, 1995; Keller and Hüsig, 2009; Parry and Kawakami, 2017; Wieland et al., 2016), as well as the support of other capabilities and services within a wider context, thus of an underlying ecosystem (Ansari et al., 2016; Flint et al., 2005; Wallenburg, 2009). In other words, the pace of substitution of innovations and new technologies is determined by the underlying ecosystem. From a theoretical perspective, an understanding of technology substitutions by examining ecosystems extends existing disruptive research - which investigated mainly whether new technologies will prevail over old technologies (Adner and Kapoor, 2016a; Christensen, 1997) - to the neglected debate of when technology prevalence will be achieved. Current literature on disruptive innovation in the global logistics industry is limited to offer directions regarding how logistics companies can manage the change from old technologies to new technologies, thus the pace of technology substitution in the global logistics industry is rarely understood.

In an attempt to close that gap, this paper investigates whether the pace of technological substitution in the global logistics sector by examining the interdependencies of the underlying ecosystems in which these technologies are embedded (Adner and Feiler, 2019; Ameer and Othman, 2012; Ansari et al., 2016; Iansiti and Levien, 2004; Talmar et al., 2018). An understanding of the interdependencies also provides a more nuanced view how ecosystems may predict disruptive or sustaining innovations (Christensen et al., 2011; Christensen, 1997). 
In particular, we ask two research questions to advance the understanding of technology substitutions and its associated ecosystems:

$R Q 1$. How do ecosystems influence the pace of technology substitution in the global logistics industry?

$R Q 2$. What determinants in the ecosystems indicate disruptive or sustaining technological innovations in the global logistics industry?

To answer these questions, we build on two subsequent steps, namely, first, building on the ecosystem framework from Adner and Kapoor (2016a), we construct a model consisting of four categories of technology substitution to assess how quickly disruptive change may occur in the global logistics industry. Second, we subsequently define key determinants of technology substitution in logistics ecosystems, thereby extending the disruptive innovation theory from Christensen (1997) through the integration of ecosystems as a distinctive element.

As such, the aim of this paper is threefold, namely, first, by categorizing the ecosystems in terms of their old and new technologies, the model provides a basis for understanding the varied implications of technology ecosystems, thereby contributing to a better understanding of the influences of ecosystems on the pace of technology substitution in the global logistics industry. Second, by linking the role of ecosystems to the concepts of disruptive and sustained technologies, this paper expands the theory of disruptive innovation, thereby showing that sustaining or disruptive innovations in the logistics industry are not driven by new technologies, but rather by technology ecosystems. Third, by defining ecosystems' determinants that influence technology substitutions in the global logistics industry, this paper not only expands ecosystem literature, but contributes to an understanding for logistics managers and academics to better predict disruptive transitions and develop strategies to allocate resources for R\&D investments either in new technologies or old technologies.

The global logistics industry has been chosen for three reasons, namely, first, innovations and the technology transitions in the global logistics industry can be regarded as a major driver of "globalization" and today's complex supply chains (Rodrigue, 2016), thus the logistics industry provides a rich source of different ecosystems and technological innovations that can be investigated. Second, the global logistics industry is challenged by digitalization and startups with potential disruptive technologies (Bharadwaj et al., 2013; Cichosz et al., 2020; Hooper and Holtbrügge, 2020; Sandström et al., 2009; Sucky and Asdecker, 2019; Tsiulin et al., 2020). In the past decade, investments in logistics start-ups are constantly growing with around US \$3.5bn in 2017 alone (Oliver Wyman, 2017), thus a better understanding of sustained or disruptive technologies may help companies to determine what strategies can be pursued to manage ecosystem interdependencies (Kapoor and McGrath, 2014). Third, the global logistics industry can be regarded as truly global, thus the innovations and technology substitutions are not geographically restricted and are subsequently disseminated on a global scale.

The remainder of the paper is structured as follows: The next chapter introduces the notion of disruptive technologies and the role of ecosystems with the two dimensions that are used to classify the pace of technology substitution. The following chapter build for categories of the pace of technology substitution and classifies specific logistics technology ecosystems along the pre-defined dimensions. This is followed by abstraction of the findings from the classification to further define determinants of technology substitution to link them to disruption innovation theory, thus extending the framework by integrating ecosystems as a crucial element to predict disruptive or sustaining innovations. 


\subsection{Disruptive technologies}

The concept of technology substitution through either sustained or disruptive innovations has become increasingly prominent in academia and practice (Adner, 2002; Ansari et al., 2016; Christensen et al., 2011; Christensen et al., 2015; Hang et al., 2015; Hüsig et al., 2005; Ozalp et al., 2018; Sampere, 2016). Generally, to better understand the threat of substitution through a new technology, scholars use the concept of the S-curve to explain the competition between technologies (Christensen, 1997; Foster, 1986; Utterback, 1994). The S-curve suggests that the performance of a new technology is relatively low in the early stages, but with a better understanding of the technology over time, the rate of progress increases. In the case of two competing technologies, Foster (1986) argues that as soon as the new technology has a superior performance compared to the old technology, the new S-curve crosses the old S-curve and the substitution threat from the new technology becomes salient.

Rogers (2003) "attributes of innovation framework" is another prominent concept that is frequently used to describe the diffusion of innovation and how technology substitution can occur. In contrast to the S-curve, which focuses on the supply side, Rogers (2003) framework focuses on the demand-side and specifically lists the factors that determine the rate of market adoption. The factors are built around how the new technology interacts with its users and considers the social context, which results in five attributes (relative advantage; compatibility; complexity; trialability; observability) that determine the market adoption of the new technology. However, while both the S-curve and Rogers (2003) framework explain how technology substitution can occur, they both fall short to distinguish between sustained and disruptive technologies.

To examine the difference between sustained and disruptive technology substitutions, scholars frequently refer to the seminal work of Christensen (1997), who distinguishes between "sustaining" and "disruptive" technologies and innovations (Table 1). "Sustained" innovations are characterized by improving products with incremental advances or major breakthroughs, thus leading to an increase in sales of the incumbents' product to most profitable customers (Christensen et al., 2015). For example, the introduction of warehouse management systems has led to processes that made warehouses activities faster for people to perform and has generated efficiencies to reduce labor-intensiveness (Lee et al., 2018; Wang et al., 2010), allowing companies to offer a discounted, and thus, more competitive price. In other words, sustaining technologies improve already existing and established services in the mainstream market (Sandström et al., 2009).

Disruptive technologies, in contrast, are initially underperforming along the dimension of mainstream customer demand and are regarded substandard by the majority of the incumbents' clients (Christensen et al, 2015). This low performance generates a market that is characterized by uncertainty, thus incumbent companies find it unreasonable to "ditch" their profitable clients for a newly established, but smaller market with an inferior technology (Sandström et al, 2009). Only when the performance and the quality of the disruptive technology rises, existing incumbents' customers are willing to abandon the sustaining technology and adopt the new technology. An example for disruptive innovation is the three-dimensional printing technology, which has the potential to disrupt existing global supply chains, but is still struggling with consumer acceptance (Boon and Van Wee, 2018; Halassi et al, 2019; Sasson and Johnson, 2016).

\subsection{The role of ecosystems}

The main argument behind the importance of ecosystems with regard to disruptive technologies is that innovation - which is crucial for a companies' survival - cannot be attributed a company single processes, but rather to complex processes involving cooperative 


\begin{tabular}{|c|c|c|c|c|}
\hline & $\begin{array}{l}\text { Performance } \\
\text { Targeted performance of the } \\
\text { product or service }\end{array}$ & $\begin{array}{l}\text { Customers } \\
\text { Targeted customers or } \\
\text { market application }\end{array}$ & $\begin{array}{l}\text { Business model } \\
\text { Impact on the required } \\
\text { business model }\end{array}$ & $\begin{array}{l}\text { Technology } \\
\text { transitions }\end{array}$ \\
\hline $\begin{array}{l}\text { Sustaining } \\
\text { innovations } \\
\text { Incumbents } \\
\text { typically } \\
\text { win }\end{array}$ & $\begin{array}{l}\text { Performance improvement in } \\
\text { attributes most valued by the } \\
\text { industry's most demanding } \\
\text { customers. These } \\
\text { improvements may be } \\
\text { incremental or breakthrough } \\
\text { in character }\end{array}$ & $\begin{array}{l}\text { The most attractive (i.e. } \\
\text { profitable) customers in the } \\
\text { mainstream markets who are } \\
\text { willing to pay for improved } \\
\text { performance }\end{array}$ & $\begin{array}{l}\text { Improves or maintains } \\
\text { profit margins by exploiting } \\
\text { the existing processes and } \\
\text { cost structures and by } \\
\text { making better use of current } \\
\text { competitive advantages }\end{array}$ & \\
\hline $\begin{array}{l}\text { Low-end } \\
\text { disruptions } \\
\text { Entrants } \\
\text { typically } \\
\text { win }\end{array}$ & $\begin{array}{l}\text { Performance that is good } \\
\text { enough along the traditional } \\
\text { metrics of performance at the } \\
\text { low-end of the main-stream } \\
\text { market }\end{array}$ & $\begin{array}{l}\text { Over-served customers in the } \\
\text { low-end of the mainstream } \\
\text { market }\end{array}$ & $\begin{array}{l}\text { Uses a new operations or } \\
\text { financial approach or both } \\
\text { to earn attractive returns at } \\
\text { the discount prices required } \\
\text { to win business at the low- } \\
\text { end of the market }\end{array}$ & \\
\hline $\begin{array}{l}\text { New-market } \\
\text { disruptions } \\
\text { Entrants } \\
\text { typically } \\
\text { win }\end{array}$ & $\begin{array}{l}\text { Lower performance in } \\
\text { "traditional" attributes, but } \\
\text { improved performance in } \\
\text { new attributes - typically } \\
\text { simplicity and convenience }\end{array}$ & $\begin{array}{l}\text { Targets non-consumption: } \\
\text { customers who historically } \\
\text { lacked the money or skill to } \\
\text { buy and use the product }\end{array}$ & $\begin{array}{l}\text { Business models must } \\
\text { make money at lower price } \\
\text { per unit sold, and at unit } \\
\text { production volumes that } \\
\text { initially will be small. Gross } \\
\text { margin dollars per unit sold } \\
\text { will be significantly lower }\end{array}$ & $\begin{array}{r}\text { Table 1. } \\
\text { Disruptive } \\
\text { innovation } \\
\text { characteristics }\end{array}$ \\
\hline
\end{tabular}

networks or business alliance: the ecosystem (Moore, 1993). Although only a few authors have linked ecosystems directly to disruption (Ansari et al., 2016; Klenner et al., 2013; Ozalp et al., 2018; Snihur et al., 2018), ecosystems have become an increasingly popular topic among academics to examine business model innovation and digital technologies (Adner, 2017; Autio et al., 2018; Autio and Thomas, 2014; Gawer and Cusumano, 2014; Stank et al., 2019). The original concept of ecosystems can be attributed to Moore (1993) - who used it as an analogy to biological ecosystems - with the aim to extend the concept of the value chain (Porter, 1985) by integrating co-evolution and the interdependencies of relevant institutional and organizational actors (Phillips and Ritala, 2019). Scholars broadly acknowledge that ecosystems require providers of complementary innovations, products or services, which may be attributed to other and different industries and need not be a bound by contractual arrangements (Jacobides et al., 2018). This complex system of interactions leads to ecosystems that are different from each other, each one with unique relationships and interdependencies.

In fact, ecosystems differ extensively between companies and organizations: for example, incumbent or traditional global logistics service providers (LSP) are often characterized by ecosystems that rely on long-term partnerships and own assets to provide transport capacity (Busse and Wallenburg, 2011; Economist, 2018; Oláh et al., 2018; Reyes, 2011). In contrast, start-ups such as digital freight forwarders (DFFs) rely on ecosystems that focus on promoting their digital platform, owning no transport capacity and no assets, but offering cost-efficient, real-time and on-demand transport arrangements (Elbert and Gleser, 2019; Oláh et al., 2018; Stölzle et al., 2018). Although both companies offer transport services, they rely on different ecosystems, which are built around different kinds of technology and what Adner and Kapoor (2016a) call the "old technology" and the "new technology." The former 
can be linked to a business ecosystem, while the latter rather represents a platform or an innovation ecosystem (Granstrand and Holgersson, 2020; Jacobides et al., 2018).

A business ecosystem focuses on an individual company and views the ecosystem as a "community of organizations, institutions and individuals that impact the enterprise and the enterprise's customers and suppliers” (Teece, 2007, p. 1325). As such, the ecosystem mirrors the business environment that the company must closely observe and react to build dynamic capabilities to maintain or gain a competitive advantage (Jacobides et al., 2018; Teece, 2010). Referring back to the example of the LSP and the potential competitor, the $\mathrm{DFF}$, this would mean that maintaining a competitive advantage for the LSP is dependent on how the LSP with the old technology can adapt and build "new" dynamic capabilities in the ecosystem to match the new technology of the DFF. In other words, the LSP needs to demonstrate that the company is able to co-evolve the old technology together with its ecosystem (for co-evolution, Holling, 2001; Phillips and Ritala, 2019) to build relevant capabilities to maintain the competitive advantage.

In contrast, new technologies rely on innovative ecosystems, which Granstrand and Holgersson (2020) defines as an "evolving set of actors, activities and artifacts and the institutions and relations, including complementary and substitute relations, that are important for the innovative performance of an actor or a population of actors" (p. 3). According to Jacobides et al. (2018), the emphasis in an innovative ecosystem lies in understanding how interdependent actors interact to build and market innovations that benefit an end customer, thus "the anchoring point is the system of innovations that allow customers to use the end product, rather than the firm" (p. 2257). Of particular interest in the context of our research is that an innovation system includes an actor or an artifact system with "substitute relations" (Granstrand and Holgersson, 2020), i.e. that an innovation ecosystem has a competitive component that aims to "substitute" old technologies with new technologies, thus representing a threat to incumbent companies to replace them. In addition, and in contrast to a business ecosystem with old technologies, innovative ecosystems with new technologies take more advantage of digital innovations, which allows the ecosystem to rival the service capabilities of incumbent firms by better coordinating distributed resources and participants (Constantinides et al., 2018).

The question that can be derived from the different ecosystems is how the old and new technology interacts to potentially substitute the old technology with the new technology, i.e. when a technological substitution occurs. In addition, research so far provides only limited answers to the question whether the pace of substitution includes determinants that indicate either sustained or disruptive innovations. As a response, this paper aims to provide insights into how ecosystems influence the pace of technology substitution in the global logistics industry to provide and identify when the substitution represents a disruptive or sustaining technology. To answer these questions, we apply Adner and Kapoor (2016a) ecosystem's framework, which consists of two dimensions that influence the pace of technology substitution in ecosystems. The first dimension concerns the "emergence challenge for new technology," is i.e. how quickly the ecosystem behind the new technology becomes sufficiently developed for its users to realize its technological potential. The second dimension concerns the "extension opportunity for old technology," i.e. how the old technology's competitiveness can be increased by improvement in the established ecosystem.

A core element in both dimensions for a substitution to happen is the "realized performance" (Adner and Kapoor, 2016a) of the new technology in the ecosystem, i.e. how the consumer perceives the performance. The performance of the new technology, however, is dependent not on its focal technology, but depends on the interaction with other elements in the ecosystem. As such, in the dimension "emergence challenge for new technology", the 
realized performance depends on the technical bottlenecks within the system. For instance, an improved lightbulb that can be plugged into an existing socket (plug-and-play) creates immediately light (Marvin, 1988). However, other technologies, depend on the development and co-innovations of other crucial parts in the ecosystem, such as a computer for the translation of this data (Adner and Kapoor, 2016a). The dimension "extension opportunity for old technology" refers to established technologies that are embedded in established ecosystems (Adner and Kapoor, 2016a; Amoako-Gyampah and Salam, 2004; Linton and Walsh, 2008). However, in contrast to new technologies, the realized performance of incumbent technologies can be accelerated by improvement in their ecosystem that offset the maturity of the focal technology. For example, although the track-and-trace systems for package deliveries has not dramatically changed in decades, their utility improves as the supporting IT infrastructure allows for more functions to be implemented (Morganti and Dablanc, 2014).

Taken together, "the pace of substitution is determined by the rate at which the new technology's ecosystem can overcome its emergence challenges relative to the rate at which the old technology's ecosystem can exploit its extension opportunities" (Adner and Kapoor, 2016b, p. 5). In the next section, building on Adner and Kapoor (2016a), we combine the two dimensions and complement their work not only by applying their model in the context of global logistics but also by examining determinants in ecosystems to highlight its role in predicting disruptive or sustaining innovations.

\section{The pace of technology substitution model}

Taken together, the dimensions of emergence challenges and extension opportunities provide an integrative model, which allows us to categorize the pace of technology substitution. While the emergence challenges reflect the degree "to which technology bottlenecks in the system constrain the new technology's realized performance from matching its potential performance", the extension opportunity represents "the extent to which improvements elsewhere in the system enhance the realized performance attainable with the old technology system" (Adner and Kapoor, 2016a, p. 629). As such, the pace of technology substitution is not a question of new technology versus old technology, but rather as a question of interplay between new technology ecosystems' and old technology ecosystems.

In this section, we combine these dimensions to build four types of technology substitution according to Adner and Kapoor (2016b), namely, illusion of resilience, robust resilience, creative destruction and robust coexistence. Figure 1 depicts the four types of technology substitution and we elaborate on each below in the context of the global logistics industry and illustrate our arguments with examples from the literature.

\subsection{Illusion of resilience}

The first type of technology substitution between old technology's ecosystems and new technology's ecosystems in the global logistics industry exhibits high emergence challenges and low extension opportunities (Adner and Kapoor, 2016b). A high emergence challenge refers to a new technology innovation, which depends on ecosystems of complementary elements, i.e. the performance of the new technology is limited by the availability and progress of other elements in its ecosystem. Low extension opportunities mean that the established ecosystem is not able to further improve the old technology. As a result, incumbent companies, relying on old technology and not being faced with an immediate threat from a new technology, remain in a stasis followed by rapid substitution - therefore, this type is labeled illusion of resilience. 


\section{RIBS}

Figure 1.

Types of technology substitution in global logistics

\begin{tabular}{|c|c|c|}
\hline \multirow{4}{*}{$\begin{array}{l}\text { Technology bottlenecks } \\
\text { in the ecosystem } \\
\text { constrain the new } \\
\text { technology's potential } \\
\text { performance } \\
\text { Low } \\
\text { The new technology's } \\
\text { ecosystem is } \\
\text { sufficiently developed } \\
\text { to realize the } \\
\text { technology's potential }\end{array}$} & $\begin{array}{l}\text { Illusion of Resilience } \\
\text { - Parcel tracking } \\
\text { - } 3 \text { D printing } \\
\text { - E-commerce - in the } \\
\text { 2000s }\end{array}$ & $\begin{array}{l}\text { Robust Resilience } \\
\text { - Electric delivery } \\
\text { vans } \\
\text { - Containerization }\end{array}$ \\
\hline & $\begin{array}{l}\text { Creative Destruction } \\
\text { - Manual vs electric } \\
\text { sorting/conveyer belt } \\
\text { E-commerce - in the } \\
2010 \mathrm{~s}\end{array}$ & $\begin{aligned} & \text { Robust Coexistence } \\
& \text { - } \text { Blockchain applications } \\
& \text { - High rack warehouse }\end{aligned}$ \\
\hline & Low & High \\
\hline & $\begin{array}{l}\text { The old technology's } \\
\text { ecosystem lacks } \\
\text { innovation to stay } \\
\text { competitive }\end{array}$ & $\begin{array}{l}\text { The old technology's } \\
\text { ecosystem can be } \\
\text { improved to stay } \\
\text { competitive }\end{array}$ \\
\hline
\end{tabular}

Degree of extension opportunity

A good example for an unexpected strike is the introduction of overnight delivery services and the real-time parcel tracking from FedEx Express in the mid-1990 (Song, 2003; Wetherbe, 2016). With Federal Express' CEO, Fred Smith famously saying: "the information about the package is just as important as the package itself" (Baldwin, 2013), the company developed a technological capability to track their packages through transit and inform customers electronically on the status of their deliveries. However, the company was dependent on complementary elements within their ecosystems and had to integrate information from all their systems (Sehgal, 2010). In other words, to build a competitive advantage that made it difficult for competitors to follow FedEx Express' new technology depended on the development and commercial deployment of other critical parts of the ecosystem, such as scanning devices and software and information management systems. For competitors, however, which relied on different ecosystems based on manual or individual processes, the development of similar services would take a considerable length of time, thus providing FedEx Express with a significant competitive advantage.

\subsection{Robust resilience}

The second type of technology substitution between old technology's ecosystems and new technology's ecosystems in the global logistics industry embodies high emergence challenges and high extension opportunities (Adner and Kapoor, 2016b). The new technology, as in the unexpected strike type, depends on other complementary elements in the ecosystems to make the technology work (Holgersson et al., 2018; Toh and Miller, 2017). Unlike the unexpected strike type, however, high extension opportunities indicate that the old technology is able to make improvements in its ecosystem to stay competitive or have 
a similar performance than the new technology. As a result, with the new technology's ecosystem being confronted by emergence challenges and the old technology's ecosystem being able to keep up with the new technology's performance, the pace of substitution will be slow - therefore, this type is labeled robust resilience.

A good example for slow takeover is the transition from fueled delivery vans to pure electric delivery vans. Although global logistics providers increasingly use electric vehicles for deliveries, it has not replaced the "traditional" fuel cars, representing only a small portion of all delivery vehicles (Kamiya and Teter, 2019). That is, although the ecosystem for electric car faces is sufficiently developed, the delivery processes and equipment are still built around the old technology, i.e. the fueled delivery car (Morganti and Browne, 2018; Wątróbski et al., 2017). However, every time car makers increase fuel-efficiency, the threshold for the electric car is raised, i.e. the gradual adjustment accelerates. In other words, the performance expectations for the innovation keep ratcheting upward, even as its increased adoption is held back by the underdeveloped state of its ecosystem (Adner and Kapoor, 2016a).

\subsection{Robust coexistence}

In the third type of technological substitution, innovations in the global logistics industry are characterized by low emergence challenges and high extension opportunities. The new technology's ecosystem is sufficiently developed, but improvements in the old technology's ecosystem will allow incumbent companies to defend their market share, leading a period of coexistence (Adner and Kapoor, 2016b). As a result, and although the extension opportunities are unlikely to reverse the rise of the new technology, they will materially delay its dominance (Adner and Kapoor, 2016a; Furr and Snow, 2015), leading to a gradual substitution - therefore, this type is labeled robust coexistence.

In the global logistics industry, blockchain technology serves as an example for a gradual adjustment or substitution. Blockchain technology poses an opportunity to digitalize processes and make logistics operations much more efficient (Hackius and Petersen, 2017; Ikeda and Marshall, 2019). While former studies emphasize the disruptive potential of blockchain technology also in the logistics sector (Dobrovnik et al., 2018; Kummer et al., 2020; Treiblmaier, 2018), which indicated an unexpected strike, recent studies see blockchain technology rather as a complementary optimization opportunity in established ecosystems (Roland Berger, 2020), as blockchain applications in the global logistics industry are built in cooperation with incumbent companies who have to overcome technological bottlenecks (Hackett, 2016; Huillet, 2020; Jones, 2018). As such, the new technology has not reached its full potential, while at the same time the old technology can be upgraded to incorporate blockchain elements to stay competitive, as the example of IBM and Maersk shows (Huillet, 2020).

\subsection{Creative destruction}

The fourth type of technological substitution exhibits low emergence challenges and low extension opportunities (Adner and Kapoor, 2016b). The new technology's ecosystem is sufficiently developed and can immediately implemented or deployed. The old technology's ecosystem does not have the capabilities to keep up with the new development, which makes the new technology achieve dominance also immediately. As a result, the new technology innovation can swiftly "destroy" the old technology, i.e. replacing it immediately in favor of the new technology - therefore, this type is labeled creative destruction.

In the global logistics industry, these new technologies often involve products and systems that enhance efficiency. A good example is the introduction of the electric conveyer belt in warehouses to distribute shipments to couriers for the last-mile delivery (Kohli, 2007; Vrgoč and Črić, 1988). Electronic conveyor belts fulfill the "plug-and-play" function as no 
complementary parts are necessary, while it replaces mostly manual processes embedded on old ecosystems. Another fast substitution in the logistics industry is the introduction of the electronic signature from customers on handheld devices, replacing fax transmissions, thereby making processes faster, safer and more efficient (Jung et al., 2006).

\section{Integrating ecosystems into disruptive innovation theory}

The categorization of the paces of technology substitution reveals certain patterns can be linked to disruptive innovation theory. In particular, certain determinants of technology substitution along the dimensions "emergence challenge for new technologies" and "extension opportunity for old technologies" allow us to draw conclusions about how the underlying ecosystems may predict either disruptive or sustained innovations. These conclusions provide not only a more nuanced insight into technology substitution but also enable us to extend Christensen (1997) disruption innovation theory by integrating of ecosystems as a crucial element to understand when technology dominance will be achieved. Table 2 presents the characteristics of disruption innovation theory extended by the role of ecosystems.

\begin{tabular}{|c|c|c|c|c|}
\hline & $\begin{array}{l}\text { Performance } \\
\text { Targeted } \\
\text { performance of the } \\
\text { product or service }\end{array}$ & $\begin{array}{l}\text { Customers } \\
\text { Targeted customers } \\
\text { or market application }\end{array}$ & $\begin{array}{l}\text { Business model } \\
\text { Impact on the } \\
\text { required business } \\
\text { model }\end{array}$ & $\begin{array}{l}\text { Ecosystems } \\
\text { Supporting } \\
\text { organism behind the } \\
\text { innovation }\end{array}$ \\
\hline $\begin{array}{l}\text { Sustaining } \\
\text { innovations } \\
\text { Incumbents } \\
\text { typically } \\
\text { win }\end{array}$ & $\begin{array}{l}\text { Performance } \\
\text { improvement in } \\
\text { attributes most } \\
\text { valued by the } \\
\text { industry's most } \\
\text { demanding } \\
\text { customers. These } \\
\text { improvements may } \\
\text { be incremental or } \\
\text { breakthrough in } \\
\text { character }\end{array}$ & $\begin{array}{l}\text { The most attractive } \\
\text { (i.e. profitable) } \\
\text { customers in the } \\
\text { mainstream markets } \\
\text { who are willing to } \\
\text { pay for improved } \\
\text { performance }\end{array}$ & $\begin{array}{l}\text { Improves or } \\
\text { maintains profit } \\
\text { margins by } \\
\text { exploiting the } \\
\text { existing processes } \\
\text { and cost structures } \\
\text { and by making } \\
\text { better use of current } \\
\text { competitive } \\
\text { advantages }\end{array}$ & $\begin{array}{l}\text { The new } \\
\text { technology's } \\
\text { ecosystem can be } \\
\text { assimilated or the } \\
\text { old technology's } \\
\text { ecosystem can be } \\
\text { improved to stay } \\
\text { competitive }\end{array}$ \\
\hline $\begin{array}{l}\text { Low-end } \\
\text { disruptions } \\
\text { Entrants } \\
\text { typically } \\
\text { win }\end{array}$ & $\begin{array}{l}\text { Performance that is } \\
\text { good enough along } \\
\text { the traditional } \\
\text { metrics of } \\
\text { performance at the } \\
\text { low-end of the main- } \\
\text { stream market }\end{array}$ & $\begin{array}{l}\text { Over-served } \\
\text { customers in the low- } \\
\text { end of the } \\
\text { mainstream market }\end{array}$ & $\begin{array}{l}\text { Uses a new } \\
\text { operations or } \\
\text { financial approach or } \\
\text { both to earn } \\
\text { attractive returns at } \\
\text { the discount prices } \\
\text { required to win } \\
\text { business at the low- } \\
\text { end of the market }\end{array}$ & $\begin{array}{l}\text { Uses "plug-and- } \\
\text { play" advancements } \\
\text { within the new } \\
\text { technology's } \\
\text { ecosystem to provide } \\
\text { a more efficient or } \\
\text { cost-effective } \\
\text { solution at the low- } \\
\text { end of the market }\end{array}$ \\
\hline $\begin{array}{l}\text { New-market } \\
\text { disruptions } \\
\text { Entrants } \\
\text { typically } \\
\text { win }\end{array}$ & $\begin{array}{l}\text { Lower performance } \\
\text { in "traditional" } \\
\text { attributes, but } \\
\text { improved } \\
\text { performance in new } \\
\text { attributes - typically } \\
\text { simplicity and } \\
\text { convenience }\end{array}$ & $\begin{array}{l}\text { Targets non- } \\
\text { consumption: } \\
\text { customers who } \\
\text { historically lacked } \\
\text { the money or skill to } \\
\text { buy and use the } \\
\text { product }\end{array}$ & $\begin{array}{l}\text { Business model must } \\
\text { make money at lower } \\
\text { price per unit sold, } \\
\text { and at unit } \\
\text { production volumes } \\
\text { that initially will be } \\
\text { small. Gross margin } \\
\text { dollars per unit sold } \\
\text { will be significantly } \\
\text { lower }\end{array}$ & $\begin{array}{l}\text { Builds on a } \\
\text { fundamentally } \\
\text { different ecosystem } \\
\text { involving often } \\
\text { different participants } \\
\text { and more complex } \\
\text { networks than } \\
\text { existing traditional } \\
\text { ecosystems' } \\
\text { processes and } \\
\text { structures }\end{array}$ \\
\hline
\end{tabular}

Table 2.

Disruptive innovation characteristics extended by ecosystems 
The interplay between the two dimensions and the subsequent categorization of the pace of technology substitution of logistics innovations revealed patterns that allow us to predict how the different ecosystems influence either sustaining or disruptive innovations. Based on our findings, we argue that if "extension opportunities for old technologies" is high, the technology represents a sustaining innovation. Sustaining innovations, according to Christensen and Raynor (2013), improve or maintain profit margins "by exploiting the existing processes and cost structures and by making better use of current competitive advantages" (p. 51). A high extension opportunity follows the same principles: the incumbent old technology has the ability to improve its established ecosystem to reach a similar or better performance than the competitor's new technology (Adner and Kapoor, 2016b), thus also making better use of current competitive advantages.

The use of blockchain technology in global logistics operations can be used to illustrate how an extension of the existing process, thus an improvement in an established ecosystem, leads to a sustained innovation. While former blockchain start-ups in logistics highlighted their potential to disrupt incumbents companies, blockchain technology in logistics, which started as a collaboration project between IBM and Maersk (Allison, 2017; Groenfeldt, 2017), has evolved to an entity called TradeLens and is dominated and controlled by incumbent companies (Huillet, 2020; Jones, 2018). According to Christensen et al. (2011), the control and dominance of the incumbent in innovations processes always leads to sustaining instead of disruptive innovations as companies cannot disrupt themselves. As a consequence, the integration of blockchain technology in the incumbents organizations' structures, processes and values ensures that blockchain in logistics represents a sustaining technology that will only improve current ecosystems and processes (Christensen and Raynor, 2013; Roland Berger, 2020). Thus, we propose that sustaining innovation occurs in an ecosystem when extension opportunities are high, i.e. the competitor's new technology's ecosystem can be assimilated or the old technology's ecosystem can be improved to stay competitive.

Consequently, if sustaining innovations are characterized by high extension opportunities for old technologies, disruptive innovations are linked to low extension opportunities. Disruptive innovations, according to Christensen and Raynor (2013), offer either a "good enough" product or service or provides an "improved performance in new attributes" (p. 51). In other words, the new innovations or technology is either cheaper or provides simpler or more convenient products or services. The low extension opportunity for the old technology can be regarded as a pre-requisite for the disruption, as the incumbents lack innovative capability within its ecosystem to stay competitive (Adner and Kapoor, 2016b).

One high-profile illustration of disruptive innovation is the rise of e-commerce through the company Amazon (Wessel and Christensen, 2012). Amazon's product - selling online and shipping - and the logistics behind the product were rather a sustaining innovation in the retail market, as Amazon targeted the same customers of brick-and-mortar stores served by incumbents. However, Amazon's subsequent growth can be explained by disruption achieved not merely through product improvements, but through the introduction of a robust and agile new business model (Christensen et al., 2011; Wieland and Wallenburg, 2012). By building a facilitated network connecting worldwide suppliers and consumers, Amazon "changed the game" (Liebmann, 2013). Eventually, e-commerce attracted traditional consumers and created a new market for "internet shopping" by challenging traditional brick-and-mortar stores. In other words, Amazon has followed a disruptive path by building its ecosystems of suppliers to match or exceed brick-and-mortar store services.

Thus, Amazon can be seen as a disruptor that targets both low-end markets and new markets. For the low-end or mainstream market, Amazon was able to use the network in its 
ecosystem to "use a new operations or financial approach or both to earn attractive returns at the discount prices required to win business at the low-end of the market" (Christensen and Raynor, 2013, p. 51). In other words, customers were able to select "good enough" products at cheaper prices, i.e. the ecosystem was built to target low-end customers, which otherwise would have not entered the traditional - more expensive - market.

Moreover, the new innovation's ecosystem requires minimal complementary elements at most (e.g. a personal computer). This represents rather a "plug-and-play" approach for customers and indicates a low emergence challenge for the new technology's ecosystem (Adner and Kapoor, 2016b). Thus, we propose that low-end disruptions occur in an ecosystem that uses "plug-and-play" advancements within the new technology's ecosystem to provide a more efficient or cost-effective solution at the low-end of the market.

For the new market, Amazon was able to use the network in its ecosystem to improve performance in new attributes and to target "customers who historically lacked the money or skill to buy and und use the product" (Christensen and Raynor, 2013, p. 51). In other words, Amazon not only provided a much greater range of products, but made product deliveries faster, simpler and more convenient, i.e. the ecosystem consists of complex innovation processes involving cooperative networks, as well as interacting organizations and individuals (Moore, 1993). Thus, we propose that new-market disruptions build on a fundamentally different ecosystem involving often different participants and more complex networks than existing traditional ecosystems' processes and structures.

\section{Conclusion}

If ecosystems affect the pace of technology substitutions, then frameworks that describes these influences and categorize substitutions according to Christensen's sustained or disruptive technologies advance organizational research. Although ecosystems have become a popular research stream among academics and practitioners, current literature is limited in its ability to describe and categorize the ecosystems' dynamics that influence the pace of technology substitutions, in particular regarding whether these substitutions are of sustained or disruptive nature. Using the global logistics industry as a case, this paper's intention has been to overcome these limitations by building frameworks that help to better understand the ecosystems' influences on technology substitution and to identify determinants that indicate whether the substitution represents a sustained or a disruptive innovation.

Specifically, to provide insight into the nature of these influences on technology substitutions, we set out to answer two questions, namely, first, we wanted to understand how ecosystems influence the pace of technology substitution in the global logistics industry and second, what determinants of technology substitution indicate disruptive or sustaining technological innovations. To answer these questions, we followed two subsequent steps. In the first step, we categorized logistics innovations and technologies according to the ecosystem framework of Adner and Kapoor (2016a) to highlight the variations in the pace of technological substitutions. In the second step, we used the predefined dimensions "emergence challenge for new technologies" and "extension opportunities for old technologies" to identify key determinants of technology substitution that can be used to predict if these technologies lead to sustaining or disruptive innovations. Based on these findings, we also proposed the first definitions of distinctive ecosystems elements linked to the three types of innovations, namely, sustaining innovations, low-end disruptions and new-market disruptions, thereby integrating ecosystems into Christensen's (1997) disruptive innovation theory. 
As such, our study makes several contributions to the theory of disruption innovation and the concept of ecosystems. First, this paper contributes to a better understanding of the influences of ecosystems on technology transitions by developing a framework that categorizes the pace of technology substitution in the global logistics industry. By categorizing the ecosystems in terms of their old and new technologies, the model provides a basis for understanding the varied implications of the ecosystems on technology substitutions. For example, a low emergence challenge and low extension opportunity indicates a quick substitution of the old technology, while a high emergence challenge and high extension opportunity indicates rather a coexistence between the old and the new technology. Second, the integration of the role of ecosystems into the concepts of disruptive and sustained technologies extents the disruptive innovation characteristics framework by Christensen and Raynor (2003) (Table 1), thereby showing that sustaining or disruptive innovations in the logistics industry are not driven by new technologies, but rather by technology ecosystems. The paper thereby links the concepts of sustained and disruptive innovations to the interaction between old and new technology ecosystems, which not only expands and refines the theory of disruptive innovation but also contributes to a more nuanced understanding how logistics managers and academics can better predict disruptive transitions and how to develop strategies to allocate resources. Third, the paper emphasizes the role of ecosystems and their influence on technology substitutions in the global logistics industry, which has been rather neglected so far. By defining ecosystems' determinants that indicate disruptive or sustained technologies, we not only expand ecosystems' literature, but help logistics firms to allocate resources for R\&D investments either in new technologies or old technologies.

These results, however, need to be viewed in the light of its limitations. The categorization and the interpretation of key determinants, although backed up by evidence, is inherently subjective, as it relies on limited examples and sources. We invite future researchers to test our model and our ecosystems' definitions in another logistics context or in another industry. Moreover, although we have examined how ecosystems influence the pace of technology substitution, a detailed investigation of the evolutionary process of disruption with regard to old and new technologies offers an avenue for future research. From an ecosystem perspective, despite having used the distinction between business ecosystems and innovation ecosystems to distinguish between old and new technologies, only limited knowledge exists regarding the interaction between these technologies, thus future research may examine the role of old and new technologies and its relation to the concepts of business ecosystems and innovation ecosystems. The framework also provides future researchers with avenues to investigate how companies can benefit from the technological interdependencies between the ecosystems. More specifically, given that the realized performance in some ecosystems rely on complementary parts, future research may examine what collaboration models, ranging from vertical integration to collaborative alliances, companies can use to gain access to these parts.

We conclude that research about the pace of technology substitution is still in its infancy, particularly in the logistics sector, which provides future researchers with an opportunity to further develop innovation models with a focus on ecosystems. By examining the role of ecosystems and linking it to the sustained and disruptive innovations, we have taken a first step toward a better understanding of the impact of ecosystems on the pace of technology substitution in the global logistics industry. We hope that both the results and the framework presented in this research will spark discussions and projects in the ecosystems and innovations sphere. 


\section{References}

Adner, R. (2002), "When are technologies disruptive? A demand-based view of the emergence of competition”, Strategic Management Journal, Vol. 23 No. 8, pp. 667-688.

Adner, R. (2017), "Ecosystem as structure: an actionable construct for strategy", Journal of Management, Vol. 43 No. 1, pp. 39-58.

Adner, R. and Feiler, D. (2019), "Interdependence, perception, and investment choices: an experimental approach to decision making in innovation ecosystems", Organization Science, Vol. 30 No. 1, pp. 109-125.

Adner, R. and Kapoor, R. (2016a), "Innovation ecosystems and the pace of substitution: re-examining technology S-curves”, Strategic Management Journal, Vol. 37 No. 4, pp. 625-648.

Adner, R. and Kapoor, R. (2016b), "Right tech, wrong time”, Harvard Business Review, Vol. 94 No. 11, pp. 60-67.

Allison, I. (2017), "Maersk and IBM want 10 million shipping containers on the global supply blockchain by year-end", available at: www.ibtimes.co.uk/maersk-ibm-aim-get-10-millionshipping-containers-onto-global-supply-blockchain-by-year-end-1609778

Ameer, R. and Othman, R. (2012), "Sustainability practices and corporate financial performance: a study based on the top global corporations", Journal of Business Ethics, Vol. 108 No. 1, pp. 61-79, doi: 10.1007/s10551-011-1063-y.

Amoako-Gyampah, K. and Salam, A.F. (2004), "An extension of the technology acceptance model in an ERP implementation environment", Information and Management, Vol. 41 No. 6, pp. 731-745.

Ansari, S., Garud, R. and Kumaraswamy, A. (2016), "The disruptor's dilemma: TiVo and the US television ecosystem”, Strategic Management Journal, Vol. 37 No. 9, pp. 1829-1853.

Autio, E. and Thomas, L. (2014), Innovation Ecosystems, Oxford University Press, Oxford.

Autio, E., Nambisan, S., Thomas, L.D. and Wright, M. (2018), "Digital affordances, spatial affordances, and the genesis of entrepreneurial ecosystems", Strategic Entrepreneurship Journal, Vol. 12 No. 1, pp. 72-95.

Autry, C.W. and Griffis, S.E. (2008), "Supply chain capital: the impact of structural and relational linkages on firm execution and innovation”, Journal of Business Logistics, Vol. 29 No. 1, pp. 157-173.

Baldwin, R. (2013), "Shipshape: tracking 40 years of FedEx tech”, Wired, available at: www.wired.com/ 2013/04/40-years-of-fedex/

Barrett, M., Davidson, E., Prabhu, J. and Vargo, S.L. (2015), "Service innovation in the digital age: key contributions and future directions”, MIS Quarterly, Vol. 39 No. 1, pp. 135-154.

Bharadwaj, A., El Sawy, O.A., Pavlou, P.A. and Venkatraman, N. (2013), "Digital business strategy: toward a next generation of insights", MIS Quarterly, Vol. 37 No. 2, pp. 471-482.

Boon, W. and Van Wee, B. (2018), "Influence of 3D printing on transport: a theory and experts judgment based conceptual model”, Transport Reviews, Vol. 38 No. 5, pp. 556-575.

Bowersox, D.J. and Daugherty, P.J. (1995), "Logistics paradigms: the impact of information technology", Journal of Business Logistics, Vol. 16 No. 1, p. 65.

Busse, C. and Wallenburg, C.M. (2011), "Innovation management of logistics service providers", International Journal of Physical Distribution and Logistics Management, Vol. 41 No. 2.

Chapman, R.L., Soosay, C. and Kandampully, J. (2003), "Innovation in logistic services and the new business model: a conceptual framework", International Journal of Physical Distribution and Logistics Management, Vol. 33 No. 7, pp. 630-650.

Christensen, C.M. (1997), The Innovator's Dilemma, Harvard Business School, Cambridge, MA.

Christensen, C.M. and Raynor, M.E. (2003), The Innovator's Solution, Harvard Business School Publishing Corporation, Boston, MA. 
Christensen, C. and Raynor, M. (2013), The Innovator's Solution: Creating and Sustaining Successful Growth, Harvard Business Review Press, Boston, MA.

Christensen, C., Raynor, M. and McDonald, R. (2011), Disruptive Innovation, Perseus Book LLC (Ingram).

Christensen, C.M., Raynor, M.E. and McDonald, R. (2015), "What is disruptive innovation", Harvard Business Review, Vol. 93 No. 12, pp. 44-53.

Cichosz, M., Wallenburg, C.M. and Knemeyer, A.M. (2020), "Digital transformation at logistics service providers: barriers, success factors and leading practices", The International Journal of Logistics Management, Vol. 31 No. 2.

Cohen, R. (2018), "How amazon's delivery logistics redefined retail supply chains", Journal of Supply Chain Management, Logistics and Procurement, Vol. 1 No. 1, pp. 75-86.

Constantinides, P., Henfridsson, O. and Parker, G.G. (2018), "Introduction-platforms and infrastructures in the digital age", Information Systems Research, Vol. 29 No. 2, pp. 381-400.

Dobrovnik, M., Herold, D., Fürst, E. and Kummer, S. (2018), "Blockchain for and in logistics: what to adopt and where to start", Logistics, Vol. 2 No. 3, p. 18, doi: 10.3390/logistics2030018.

Economist, T. (2018), "The global logistics business is going to be transformed by digitization", The Economist, available at: www.economist.com/briefing/2018/04/26/the-global-logistics-businessis-going-to-be-transformed-by-digitisation

Elbert, R. and Gleser, M. (2019), “Digital forwarders”, Logistics Management, Springer, pp. 19-31.

Flint, D.J., Larsson, E., Gammelgaard, B. and Mentzer, J.T. (2005), "Logistics innovation: a customer value-oriented social process”, Journal of Business Logistics, Vol. 26 No. 1, pp. 113-147.

Foster, R.N. (1986), Innovation: The Attacker's Advantage, Summit books, New York, NY.

Furr, N.R. and Snow, D.C. (2015), "Intergenerational hybrids: spillbacks, spillforwards, and adapting to technology discontinuities", Organization Science, Vol. 26 No. 2, pp. 475-493.

Gawer, A. and Cusumano, M.A. (2014), "Industry platforms and ecosystem innovation", Journal of Product Innovation Management, Vol. 31 No. 3, pp. 417-433.

Goldsby, T.J. and Zinn, W. (2016), "Technology innovation and new business models: can logistics and supply chain research accelerate the evolution?", Journal of Business Logistics, Vol. 37 No. 2, pp. 80-81.

Granstrand, O. and Holgersson, M. (2020), "Innovation ecosystems: a conceptual review and a new definition", Technovation, Vol. 90, p. 102098.

Groenfeldt, T. (2017), "IBM and Maersk apply blockchain to container shipping", Forbes, available at: www.forbes.com/sites/tomgroenfeldt/2017/03/05/ibm-and-maersk-apply-blockchain-tocontainer-shipping

Hackett, R. (2016), "Walmart and IBM are partnering to put Chinese pork on a blockchain”, Forbes, available at: http://fortune.com/2016/10/19/walmart-ibm-blockchain-china-pork

Hackius, N. and Petersen, M. (2017), "Blockchain in logistics and supply chain: trick or treat?", Paper presented at the Proceedings of the Hamburg International Conference of Logistics (HICL).

Halassi, S., Semeijn, J. and Kiratli, N. (2019), "From consumer to prosumer: a supply chain revolution in 3D printing", International Journal of Physical Distribution and Logistics Management.

Hang, C.C., Garnsey, E. and Ruan, Y. (2015), “Opportunities for disruption”, Technovation, Vols 39/40, pp. 83-93.

Hayut, Y. (1981), "Containerization and the load center concept”, Economic Geography, Vol. 57 No. 2, pp. 160-176.

Holgersson, M., Granstrand, O. and Bogers, M. (2018), "The evolution of intellectual property strategy in innovation ecosystems: uncovering complementary and substitute appropriability regimes", Long Range Planning, Vol. 51 No. 2, pp. 303-319. 
Holling, C.S. (2001), "Understanding the complexity of economic, ecological, and social systems", Ecosystems, Vol. 4 No. 5, pp. 390-405.

Hooper, A. and Holtbrügge, D. (2020), "Blockchain technology in international business: changing the agenda for global governance", Review of International Business and Strategy, Vol. 30 No. 2, pp. 183-200.

Huillet, M. (2020), "Standard chartered joins IDM and Maersk's blockchain shipping platform", Cointelegraph, available at: https://cointelegraph.com/news/standard-chartered-joins-ibm-andmaersks-blockchain-shipping-platform

Hüsig, S., Hipp, C. and Dowling, M. (2005), "Analysing disruptive potential: the case of wireless local area network and mobile communications network companies”, R\&D Management, Vol. 35 No. 1, pp. 17-35.

Iansiti, M. and Levien, R. (2004), The Keystone Advantage: What the New Dynamics of Business Ecosystems Mean for Strategy, Innovation, and Sustainability, Harvard Business Press, Boston, MA.

Ikeda, K. and Marshall, A. (2019), "Strategies for competing in markets enabled by digital platforms", Strategy and Leadership, Vol. 40 No. 1, pp. 30-36.

Jacobides, M.G., Cennamo, C. and Gawer, A. (2018), "Towards a theory of ecosystems", Strategic Management Journal, Vol. 39 No. 8, pp. 2255-2276.

Jones, M. (2018), "Maersk and IBM launch TradeLens blockchain shipping solution from beta", TheBlock, available at: https://blockchaintechnology-news.com/2018/08/maersk-ibm-launchtradeles-blockchain-shipping-solution-from-beta/

Jung, H., Lee, K. and Chun, W. (2006), "Integration of GIS, GPS, and optimization technologies for the effective control of parcel delivery service", Computers and Industrial Engineering, Vol. 51 No. 1, pp. 154-162.

Kamiya, G., Teter, J. (2019), "Shared, automated... and electric?", International Energy Agency, available at: www.iea.org/commentaries/shared-automated-and-electric

Kapoor, R. and McGrath, P.J. (2014), "Unmasking the interplay between technology evolution and R\&D collaboration: evidence from the global semiconductor manufacturing industry, 1990-2010", Research Policy, Vol. 43 No. 3, pp. 555-569.

Keller, A. and Hüsig, S. (2009), "Ex ante identification of disruptive innovations in the software industry applied to web applications: the case of Microsoft's vs Google's office applications", Technological Forecasting and Social Change, Vol. 76 No. 8, pp. 1044-1054.

Klenner, P., Hüsig, S. and Dowling, M. (2013), "Ex-ante evaluation of disruptive susceptibility in established value networks - when are markets ready for disruptive innovations?”, Research Policy, Vol. 42 No. 4, pp. 914-927.

Klötzer, C. and Pflaum, A. (2017), "Toward the development of a maturity model for digitalization within the manufacturing industry's supply chain".

Kohli, R. (2007), "Innovating to create IT-based new business opportunities at united parcel service", MIS Quarterly Executive, Vol. 6 No. 4.

Kothman, I. and Faber, N. (2016), "How 3D printing technology changes the rules of the game", Journal of Manufacturing Technology Management, Vol. 27 No. 7.

Kummer, S., Herold, D.M., Dobrovnik, M., Mikl, J. and Schäfer, N. (2020), “A systematic review of blockchain literature in logistics and supply chain management: identifying research questions and future directions", Future Internet, Vol. 12 No. 3, p. 60.

Lee, C., Lv, Y., Ng, K., Ho, W. and Choy, K. (2018), "Design and application of internet of things-based warehouse management system for smart logistics", International Journal of Production Research, Vol. 56 No. 8, pp. 2753-2768.

Liebmann, W. (2013), “Amazon changes the game. . again”, Forbes, available at: www.forbes.com/ sites/wendyliebmann/2013/06/25/amazon-changes-the-game-again/\#155b0ec72dfb 
Linton, J.D. and Walsh, S.T. (2008), "Acceleration and extension of opportunity recognition for nanotechnologies and other emerging technologies", International Small Business Journal: Researching Entrepreneurship, Vol. 26 No. 1, pp. 83-99.

Marvin, C. (1988), When Old Technologies Were New: Thinking about Electric Communication in the Late Nineteenth Century, Oxford University Press.

Moore, J.F. (1993), "Predators and prey: a new ecology of competition", Harvard Business Review, Vol. 71 No. 3, pp. 75-86.

Morganti, E. and Browne, M. (2018), "Technical and operational obstacles to the adoption of electric vans in France and the UK: an operator perspective", Transport Policy, Vol. 63, pp. 90-97.

Morganti, E. and Dablanc, L. (2014), "Recent innovation in last mile deliveries", Non-Technological Innovations for Sustainable Transport, Springer, pp. 27-45.

Notteboom, T. and Rodrigue, J.-P. (2009), "The future of containerization: perspectives from Maritime and inland freight distribution", GeoJournal, Vol. 74 No. 1, p. 7.

Oláh, J., Karmazin, G., Pet”, K. and Popp, J. (2018), "Information technology developments of logistics service providers in Hungary", International Journal of Logistics Research and Applications, Vol. 21 No. 3, pp. 332-344.

Oliver Wyman (2017), "Digital logistics startups are both challenge and opportunity for industry incumbents", Forbes, available at: www.forbes.com/sites/oliverwyman/2017/07/28/digitallogistics-startups-are-both-challenge-and-opportunity-for-industry-incumbents/\#66d1000e1589

Ozalp, H., Cennamo, C. and Gawer, A. (2018), "Disruption in platform-based ecosystems", Journal of Management Studies, Vol. 55 No. 7, pp. 1203-1241.

Parry, M.E. and Kawakami, T. (2017), "The encroachment speed of potentially disruptive innovations with indirect network externalities: the case of E-readers", Journal of Product Innovation Management, Vol. 34 No. 2, pp. 141-158.

Phillips, M.A. and Ritala, P. (2019), "A complex adaptive systems agenda for ecosystem research methodology", Technological Forecasting and Social Change, Vol. 148, p. 119739.

Porter, M.E. (1985), Competitive Strategy: Creating and Sustaining Superior Performance, Free Press, New York, NY.

Reyes, P.M. (2011), RFID in the Supply Chain, McGraw Hill Professional.

Rodrigue, J.P. (2016), The Geography of Transport Systems, Routledge, New York, NY.

Rogers, E.M. (2003), Diffusion of Innovations, Simon and Schuster, New York, NY.

Roland Berger (2020), "Freight tech - advancing the future of logistics", available at: www.rolandberger. com/en/Publications/FreightTech-The-future-of-logistics.html

Sampere, J.V. (2016), "Why platform disruption is so much bigger than product disruption”, Harvard Business Review.

Sandström, C., Magnusson, M. and Jörnmark, J. (2009), 'Exploring factors influencing incumbents' response to disruptive innovation", Creativity and Innovation Management, Vol. 18 No. 1, pp. 8-15.

Sasson, A. and Johnson, J.C. (2016), "The 3D printing order: variability, supercenters and supply chain reconfigurations", International Journal of Physical Distribution and Logistics Management, Vol. 46 No. 1.

Sehgal, V. (2010), Supply Chain as Strategic Asset: The Key to Reaching Business Goals, John Wiley and Sons.

Snihur, Y., Thomas, L.D. and Burgelman, R.A. (2018), “An ecosystem-level process model of business model disruption: the disruptor's gambit”, Journal of Management Studies, Vol. 55 No. 7, pp. 1278-1316.

Song, H. (2003), "E-services at FedEx", Communications of the ACM, Vol. 46 No. 6, pp. 45-46.

Stank, T., Esper, T., Goldsby, T.J., Zinn, W. and Autry, C. (2019), "Toward a digitally dominant paradigm for twenty-first century supply chain scholarship", International Journal of Physical Distribution and Logistics Management, Vol. 49 No. 10, pp. 956-971. 
Stölzle, W., Schmidt, T., Kille, C., Schulze, F. and Wildhaber, V. (2018), Digitalisierungswerkzenge in Der Logistik: Einsatzpotenziale, Reifegrad Und Wertbeitrag, Cuvillier Verlag, Göttingen.

Sucky, E. and Asdecker, B. (2019), "Digitale Transformation der Logistik-Wie verändern neue Geschäftsmodelle die Branche?”, Geschäftsmodelle in Der Digitalen Welt, Springer, pp. 191-212.

Talmar, M., Walrave, B., Podoynitsyna, K.S., Holmström, J. and Romme, A.G.L. (2018), “Mapping, analyzing and designing innovation ecosystems: the ecosystem pie model”, Long Range Planning, p. 101850.

Teece, D.J. (2007), "Explicating dynamic capabilities: the nature and microfoundations of (sustainable) enterprise performance”, Strategic Management Journal, Vol. 28 No. 13, pp. 1319-1350.

Teece, D.J. (2010), "Business models, business strategy and innovation”, Long Range Planning, Vol. 43 Nos 2/3, pp. 172-194, doi: 10.1016/j.lrp.2009.07.003.

Toh, P.K. and Miller, C.D. (2017), "Pawn to save a chariot, or drawbridge into the fort? Firms' disclosure during standard setting and complementary technologies within ecosystems", Strategic Management Journal, Vol. 38 No. 11, pp. 2213-2236.

Treiblmaier, H. (2018), "The impact of the blockchain on the supply chain: a theory-based research framework and a call for action”, Supply Chain Management: An International Journal.

Tsiulin, S., Reinau, K.H., Hilmola, O.P., Goryaev, N. and Karam, A. (2020), "Blockchain-based applications in shipping and port management: a literature review towards defining key conceptual frameworks", Review of International Business and Strategy, Vol. 30 No. 2, pp. 201-224.

Utterback, J. (1994), Mastering the Dynamics of Innovation: How Companies Can Seize Opportunities in the Face of Technological Change, Harvard Business School Press, Boston, MA.

Vrgoč, M. and Čerić, V. (1988), "Investigation and design of parcel sorting systems in postal centres by simulation", Computers in Industry, Vol. 10 No. 2, pp. 137-145.

Wallenburg, C.M. (2009), "Innovation in logistics outsourcing relationships: proactive improvement by logistics service providers as a driver of customer loyalty", Journal of Supply Chain Management, Vol. 45 No. 2, pp. 75-93.

Wang, H., Chen, S. and Xie, Y. (2010), "An RFID-based digital warehouse management system in the tobacco industry: a case study", International Journal of Production Research, Vol. 48 No. 9, pp. 2513-2548.

Wątróbski, J., Małecki, K., Kijewska, K., Iwan, S., Karczmarczyk, A. and Thompson, R.G. (2017), "Multicriteria analysis of electric vans for city logistics", Sustainability, Vol. 9 No. 8, p. 1453.

Wessel, M. and Christensen, C.M. (2012), "Surviving disruption", Harvard Business Review, Vol. 90 No. 12 , pp. 56-64.

Wetherbe, J. (2016), “FedEx: obtaining corporate sponsored research”, Entrepreneur and Innovation Exchange.

Wieland, A. and Wallenburg, C.M. (2012), "Dealing with supply chain risks", International Journal of Physical Distribution and Logistics Management, Vol. 42 No. 10.

Wieland, A., Handfield, R.B. and Durach, C.F. (2016), "Mapping the landscape of future research themes in supply chain management", Journal of Business Logistics, Vol. 37 No. 3, pp. 205-212.

\section{Corresponding author}

David M. Herold can be contacted at: dherold@wu.ac.at

For instructions on how to order reprints of this article, please visit our website:

www.emeraldgrouppublishing.com/licensing/reprints.htm

Or contact us for further details: permissions@emeraldinsight.com 